\title{
Heterogeneity in the prevalence and intensity of bovine trypanosomiasis in the districts of Amuru and Nwoya, Northern Uganda
}

Harriet Angwech ${ }^{1 *}$, Jack H. P. Nyeko ${ }^{1}$, Elizabeth A. Opiyo ${ }^{1}$, Joseph Okello-Onen ${ }^{1 \wedge}$, Robert Opiro ${ }^{1}$, Richard Echodu Geoffrey M. Malinga ${ }^{1,3}$, Moses N. Njahira ${ }^{2}$ and Robert A. Skilton²

\begin{abstract}
Background: Livestock trypanosomiasis, transmitted mainly by tsetse flies of the genus Glossina is a major constraint to livestock health and productivity in the sub-Saharan Africa. Knowledge of the prevalence and intensity of trypanosomiasis is important in understanding the epidemiology of the disease. The objectives of this study were to (a) assess the prevalence and intensity of trypanosome infections in cattle, and (b) to investigate the reasons for the heterogeneity of the disease in the tsetse infested districts of Amuru and Nwoya, northern Uganda.

Methods: A cross-sectional study was conducted from September, 2011 to January, 2012. Blood samples were collected from 816 cattle following jugular vein puncture, and screened for trypanosomes by HCT and ITS-PCR. A Pearson chi-squared test and logistic regression analyses were performed to determine the association between location, age, sex, and prevalence of trypanosome infections.

Results: Out of the 816 blood samples examined, 178 (22\%) and 338 (41\%) tested positive for trypanosomiasis by HCT and ITS-PCR, respectively. Trypanosoma vivax infection accounted for $77 \%$ of infections detected by ITS-PCR, T. congolense (16 \%), T. brucei s.l (4\%) and mixed (T. vivax/ T. congolense/T.brucei) infections (3\%). The risk of trypanosome infection was significantly associated with cattle age $\left(X^{2}=220.4, \mathrm{df}=3, P<0.001\right)$. The highest proportions of infected animals were adult males $(26.7 \%)$ and the least infected were the less than one year old calves (2.0\%). In addition, the risk of trypanosome infection was significantly associated with sex $\left(X^{2}=16.64, \mathrm{df}=1, P<0.001\right)$, and males had a significantly higher prevalence of infections (26.8\%) than females (14.6\%).
\end{abstract}

Conclusion: Our results indicate that the prevalence and intensity of trypanosome infections are highly heterogeneous being associated with cattle age, location and sex.

Keywords: Cattle, ITS-PCR, Risk factors, T. brucei s.I, T. congolense, T. vivax, Trypanosomiasis

\section{Background}

Trypanosomiasis, caused by several species of Trypanosoma, is an economically important disease affecting both humans and domestic animals. African trypanosomiasis is transmitted mainly by tsetse flies of the genus Glossina known to be distributed widely between latitudes $14^{\circ} \mathrm{N}$ and $29^{\circ} \mathrm{S}$ of the equator in $37 \mathrm{Sub}-$ Saharan countries [1]. Trypanosoma vivax is also

\footnotetext{
*Correspondence: angwechh@yahoo.com

Deceased

'Department of Biology, Faculty of Science, Gulu University, P.O. Box 166, Gulu, Uganda

Full list of author information is available at the end of the article
}

transmitted mechanically by biting flies such as Tabanus and Stomoxys. The disease excludes livestock and farming systems from about $70 \%$ of the humid and semihumid zones of sub-Saharan Africa [2]. Schofield and Kabayo [3] estimated the losses to Africa's Gross Domestic Product (GDP) due to trypanosomiasis infection at about 4.5 billion US dollars annually, including the approximately three million cattle deaths.

Uganda is affected by Human African Trypanosomiasis (HAT) caused by two Trypanosoma brucei sub-species: Trypanosoma brucei gambiense in the northwest, and Trypanosoma brucei rhodesiense in the southeast and northeast of the country [1]. Recent studies have 
shown the possibility of the two sub-species merging in the country [4]. The epidemiology of HAT is quite complex, with transmission cycles involving interactions between man, tsetse and trypanosomes, and in the case of T. $b$. rhodesiense disease, domestic and wild animals play a significant role as well. In cattle, Trypanosoma brucei brucei, Trypanosoma congolense and Trypanosoma vivax are species of economic importance.

It has been observed in previous studies that contact between blood feeding insects such as tsetse flies and their respective hosts is highly heterogeneous and nonrandom [5-7]. As a result, some hosts are bitten more than others, contributing more to the transmission of parasites. The concept of host heterogeneity has been shown to have important implications for disease transmission and to a great extent the design of disease control interventions [8, 9]. Identification of heterogeneities inherent to vector-borne disease systems is a basis for the development of local and adaptive control strategies that efficiently make use of limited resources [10].

Over the years, a number of methods for control of tsetse flies and trypanosomiasis have been developed [11]. These include, treatment of infected animals, aerial spraying, use of animal baits, sterile insect technique, clearing of tsetse infested bushes and slaughtering wild animals. In Uganda, control of trypanosomiasis relies heavily on curative treatment of livestock and the use of tsetse traps. However, there has been significant problem of parasite resistance to trypanocides $[12,13]$. Yet the development of new efficacious drugs is considered unprofitable by most pharmaceutical industries considering that this is a disease that affects mainly the rural poor [14]. Thus there is need to develop adaptive control options that are suitable for the resource poor communities in the sub-Saharan Africa. This might be possible if curative treatments target infected animals only, and prophylactic and insecticide treatments target only animals that are challenged most in the herd.

Furthermore, the knowledge of the prevalence and distribution of trypanosome species in a geographical area is essential for understanding the epidemiology of the disease. This information is, however, lacking for the northern Uganda districts of Nwoya and Amuru that have suffered a setback in research due to the prolonged insurgency in the region. The objectives of this study were to (a) assess the prevalence and intensity of bovine trypanosomiasis, and (b) investigate the reason for the heterogeneity of the disease in the tsetse infested districts of Amuru and Nwoya, Uganda.

\section{Materials and methods}

\section{Study area}

This study was conducted in the districts of Amuru $\left(02^{\circ}\right.$ $\left.48^{\prime} 49^{\prime \prime} \mathrm{N}, 31^{\circ} 56^{\prime} 19^{\prime \prime} \mathrm{E}\right)$ and Nwoya $\left(02^{\circ} 38^{\prime} 15^{\prime \prime} \mathrm{N}, 32^{\circ} 00^{\prime}\right.$ $53 " \mathrm{E})$ in northern Uganda, that borders the Murchison
Falls National Park (Fig. 1). The two districts lie in the animal trypanosomiasis endemic areas and also fall within a Gambiense focus with cases of Gambian sleeping sickness reported annually [15]. Subsistence agriculture is the main economic activity of the districts, employing up to $98 \%$ of the population. The arable land constitutes $90 \%$ of the total land area in the districts, and is very fertile (Amuru District Development plan 2011-2016). However, during the last twenty years of prolonged insurgency, there was no form of vector control in place and less than $1 \%$ of the land was utilized for agriculture, and as a result the area became re-invaded by tsetse and other biting flies.

The area has two rainfall periods, July to November and March to May, with a short dry spell in June and a fairly long period of dryness from December to February. The mean annual rainfall is about 1000 to 2000 $\mathrm{mm}$. The average daily minimum and maximum temperatures are $25{ }^{\circ} \mathrm{C}$ and $39{ }^{\circ} \mathrm{C}$, respectively [16]. The climate is favourable for agriculture and is conducive for the proliferation of tsetse flies, the vectors for African trypanosomiasis, with Glossina fuscipes fuscipes being a major species (99\%) (Angwech et al. unpublished observation). Both districts lie within the savannah grassland and are crossed by several rivers and streams. The population density of cattle in the area ranges between 10 and 20 individuals per square kilometer [17].

All parishes in Nwoya district included in the study border Murchison falls national park (i.e they are found in the wildlife-livestock interface), where wild animals used to wander freely in the course of the insurgency when the inhabitants lived in protected IDP camps in trading centers. Cattle are now being reintroduced as part of the national restocking and peace recovery programme of the government of Uganda. The density of livestock, as compared to game animals, is generally low. Therefore, tsetse flies largely depend on game animals for blood meals but also feed on livestock (Angwech et al., unpublished observation). Amuru's parishes on the other hand are located in an area where the density of game animals is low and therefore, livestock constitute the main source of tsetse blood meal.

\section{Sample size determination}

The expected sample size for the number of cattle was determined using the formula provided by Kish [18] assuming a confidence interval of $95 \%$, a level of expected prevalence of $50 \%$ and an assumed precision of $5 \%$ given that there was no prior information about the prevalence of trypanosomiasis infection in the area. This approach generated an approximate sample size of 816 .

\section{Study design and sampling}

A cross-sectional survey design was used to determine the prevalence and intensity of trypanosome species in 


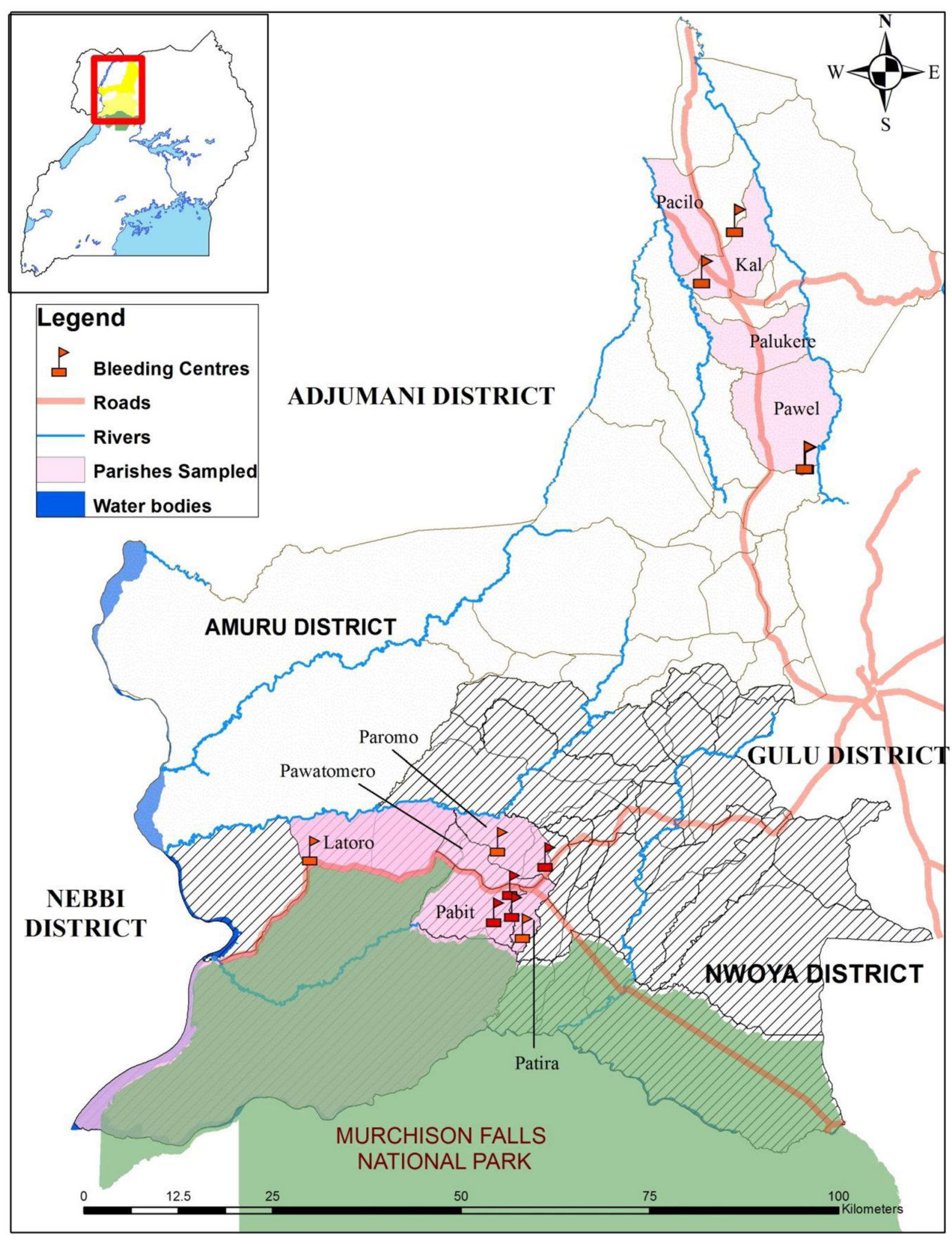

Fig. 1 Location of study sites in Amuru and Nwoya districts, northern Uganda (Sampled parishes and bleeding centers). All parishes in Nwoya district included in the study border Murchison Falls National Park (i.e. they are found in the wildlife-livestock interface). Amuru's parishes on the other hand are located in an area where the density of game animals is low and therefore, livestock constitute the main source of tsetse blood meal 
cattle from September, 2011 to January, 2012. Two subcounties of Atiak and Purongo in Amuru and Nwoya, respectively, were randomly selected for the study based on the information provided by the district veterinary departments about tsetse infestation in the area and trypanosome-attributable deaths of cattle. From these two sub-counties, nine parishes (Patira, Pawatomero, Latoro, Paromo, Pabit, Kal, Palukere, Pawel and Pacilo) were randomly selected for the study and bleeding centers were established in every parish. Cattle were categorized in to the following age groups: $<12$ months; 12 to 48 months and $>48$ months. Calves included in this study were only those herded together with other herds under communal grazing system. The ages of cattle were determined based on dentition [19] and information provided by the farmers. All cattle presented for bleeding at the centers were included in the study in order to realize the sample size. In total 816 blood samples (460 males, 356 females) were collected from 19 herds of cattle distributed in the nine parishes of Nwoya and Amuru districts $($ Patira $=81$; Pawatomero $=86$; Latoro $=87$; Paromo $=103 ; \quad$ Pabit $=90 ; \quad \mathrm{Kal}=87 ; \quad$ Palukere $=70$, Pawel $=127$ and Pacilo $=85$ ).

\section{Ethical consideration}

This research was approved by the Gulu University Institutional Review Board and by the Uganda National Council for Science and Technology. Farmers accepted to participate in the study by signing the consent forms that were provided to them before the animals were bled. Bleeding was done by trained field veterinarians.

\section{Blood sample collection}

The animals used in this study were mainly local Boran short-horn zebu cattle under traditional communal grazing system. For each animal, whole blood sample was drawn into heparinised vacutainer tubes from the jugular vein. Four blood spots (each $120 \mu \mathrm{l}$ ) were made on a single Whatman ${ }^{\circ}$ Classic FTA Card (Whatman Bioscience, Cambridge, UK) according to the manufacturer's instructions. The spots were air-dried at ambient room temperature, and the cards stored moisture-free in silica gel awaiting DNA extraction.

\section{Parasitological tests}

Screening of all blood samples for trypanosomes was carried out using haematocrit centrifugation technique (HCT) [20], complemented with direct smears. Parasitological tests for all samples were carried out in the field immediately following blood collection. To perform HCT, three capillary tubes were filled by capillary attraction up to the $3 / 4$ mark with uncoagulated blood. Each capillary tube was then sealed at one end using plasticin, centrifuged at 10,000 rpm for 5 min to obtain the buffy coat, and examined for the presence of trypanosomes under a compound microscope (Olympus, magnification $\times 40$ ). For direct smears, the capillary tubes were cut with a diamond-tipped pencil, and the buffy coat was examined microscopically to detect the presence of motile trypanosomes [21]. This was done for all HCT negative samples. All parasitologically positive animals were given a single curative dose of diminazene aceturate (Berenil ${ }^{\circ}, 3.5 \mathrm{mg} \mathrm{kg}^{-1}$ body weight). Parasitaemia scores resulting from trypanosome infections in this study were categorized for intensity using a parasitaemia score from 1 (lowest intensity) to 6 (highest intensity), adopted from ILCA [22]. Scores were assigned as follows: 1 [below 10]; 2[10-20]; 3[21-30]; 4[31-40]; 5[41-50] and 6 for more than 50 parasites observed per 50 random fields of view. These values were then organized into classes to ease the analysis and interpretation of results.

\section{DNA extraction from FTA cards}

Using a Harris 3-mm micro-punch (Whatman Biosciences Ltd.), five sample discs were cut randomly from a dried blood spot and placed into a $1.5 \mathrm{ml}$ Eppendorf tube to reduce the chance of missing out trypanosome DNA. To prevent contamination between samples, punches were cleaned after every sampling using a $5 \%$ sodium hypochlorite and $70 \%$ ethanol. The punch was then used to cut a clean filter paper before using it on the next sample. DNA extraction was done using the Invitrogen $^{\mathrm{Tm}}$ PureLink Genomic DNA kit for purification of genomic DNA (Invitrogen Inc.) following the manufacturer's instructions. DNA quality and quantity were checked using nanoDrop spectrophotometry and gel electrophoresis. The purified DNA sample was used immediately for PCR analyses or stored at $-20{ }^{\circ} \mathrm{C}$ until use.

\section{PCR amplification of DNA}

All parasitologically positive and negative extracted DNA samples were subjected to Internal Transcribed Spacers (ITS)1 Polymerase Chain Reaction (PCR) amplification using ITS1 CF (5'CCGGAAGTTCACCGATATTG-3') and ITS1 BR (5'TTGCTGCGTTCTTCAACGAA-3') as the forward and reverse primers, respectively. These primers amplify ITS1 region of rDNA genes which are known to vary in size within trypanosome species, and therefore differentiate trypanosome species by their ITS1 sizes [23-25]. All primers were supplied by Bioneer Corporation. The PCR amplifications were performed in a total reaction volume of $20 \mu \mathrm{L}$ containing $10 \mu \mathrm{M}$ of each primer, the Bioneer AccuPower ${ }^{\circ}$ PCR premix (Bioneer Corporation), and $2 \mu \mathrm{L}$ of each DNA template. All PCR amplifications were performed with a thermal cycler (GeneAmp 9700 PCR system, Applied Biosystems). PCR cycling for ITS1 CF and BR primers involved an initial denaturation at $94{ }^{\circ} \mathrm{C}$ for 5 min, followed by 35 cycles of $94{ }^{\circ} \mathrm{C}$ each for $40 \mathrm{~s}, 58{ }^{\circ} \mathrm{C}$ for $40 \mathrm{~s}$, followed by $72{ }^{\circ} \mathrm{C}$ for 
$90 \mathrm{~s}$, and final extension at $72{ }^{\circ} \mathrm{C}$ for $5 \mathrm{~min}$ [25]. To ensure that results were not biased by false positives during repeated PCRs, negative controls in which DNA templates were replaced with sterile water as well as positive control DNAs (of each trypanosome species) were included in all PCR reactions. A $4.0 \mu \mathrm{L}$ of each amplified PCR product was electrophoresed on a $1.5 \%$ agarose gel in $0.5 \mathrm{X}$ TBE. A $1 \mathrm{~Kb}$ plus DNA size ladder (Fermentas) was included on each gel, stained in Gel Red dye, run constantly at 100 $\mathrm{V}$ for $45 \mathrm{~min}$ and visualized under ultraviolet transillumination. To confirm the results, the selected PCR products for positive samples were column purified using the GeneJet ${ }^{\mathrm{TM}}$ PCR purification kit (Fermentas Life Sciences) following the manufacturer's instructions. Sequencing was done at the BecA-ILRI Hub Sequencing, Genotyping, OligoSynthesis and Proteomics (SEGoLIP) department using both the forward and reverse amplification primers. Sequences were edited in CLC Main Workbench 6.6.5 software (CLC Bio) and blasted to determine their identity. This was done particularly because there were PCR products that produced bands which did not correspond to any known pathogenic trypanosome species band size.

\section{Statistical analysis}

A Pearson chi-squared test and logistic regression analyses were used to determine the association between location, age, sex, and prevalence of trypanosome infections. The threshold for significance was $5 \%$. All statistical tests were performed using SPSS software (version 16.0.1, SPSS Inc., Chicago, IL, USA).

\section{Results}

Out of the 816 blood samples screened for trypanosome infections, 178 (22\%) and 338 (41 \%) animals tested positive by parasitological diagnostic tools (HCT and Direct smears) and ITS PCR, respectively. A total of $77 \%$ of the infections detected by ITS PCR was caused by $T$. vivax, T. congolense (16\%), T. brucei s.l (4\%) and mixed (T. vivax/ T. congolense/T.brucei) infections (3\%). All the three $T$. congolense sub-types ( $T$. congolense 'forest', $T$. congolense kilifi' and T. congolense 'savanah') were found infecting cattle in the study area.

\section{Prevalence of trypanosome infections by location}

There was a significant association between district location and the prevalence of trypanosome infections $\left(X^{2}=8.28, \mathrm{df}=1, P=0.004\right)$. The risk of trypanosome infections was 2.5 times higher in Amuru than in Nwoya district. Furthermore, the prevalence of infections was significantly associated with the parish location $\left(\chi^{2}=39.59, \mathrm{df}=8, \quad P<0.001\right)$. The highest prevalence of trypanosome infections was in Pawel parish in Amuru district and the lowest was in Patira parish,

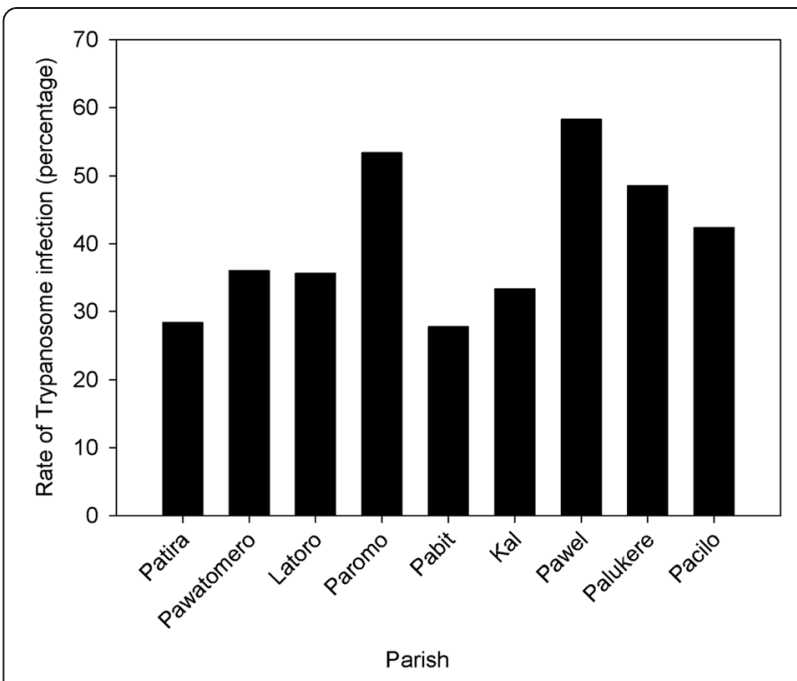

Fig. 2 The prevalence of bovine trypanosomiasis in the nine parishes of Amuru and Nwoya districts, northern Uganda

Nwoya district (Fig. 2). The risk of trypanosome infections was 1.6 times higher in Pawel than in Patira parish (OR 2.60; 95 \% CI: (1.36-4.98); $P=0.004)$.

The association between cattle age and trypanosomiasis There was a significant association between age of cattle and the prevalence of trypanosome infections $\left(\chi^{2}=\right.$ $73.08, \mathrm{df}=2, P<0.001)$. The risk of trypanosome infections was nine times higher in males above 48 months of age (OR 10.0; 95\% CI: (5.6-17.9); $P<0.001)$ and almost six times higher in cows above 48 months of age (OR 6.1; 95 \% CI: $(3.8-9.1) ; P<0.001)$ than in calves (Table 1). Furthermore, the parasitaemia scores resulting from trypanosome infections were lower in calves than in adults. Table 2 indicates that, in general, $67 \%$ of all detected parasitaemias in calves were scored 1 or 2 , i.e. less than 20 parasites observed per 50 random fields of view.

The association between sex and trypanosome infections There was a significant association between sex of cattle and trypanosome infections $\left(\chi^{2}=16.64, \mathrm{df}=1, \quad P<\right.$ $0.001)$. Males were associated with a higher risk of trypanosomiasis $(26.7 \%)$ than females (14.6\%; OR 0.49; 95 \% CI: $0.36-0.68 ; P=0.001)$.

\section{Discussion}

In the present study, we found a significant association between age of cattle and the prevalence of trypanosome infections. A higher prevalence and intensity of trypanosome infections was found in adult cattle (males and females whose ages were greater than 48 months) than in calves less than twelve months (Table 1). Similar results have been found in several previous studies [6, 26-29]. This could be attributed to differences in the period of exposure 
Table 1 The prevalence and relative risks of trypanosome infections in cattle of different age categories and sex

\begin{tabular}{|c|c|c|c|c|c|}
\hline \multirow[t]{2}{*}{ Age / sex } & \multirow[t]{2}{*}{$N$} & \multirow{2}{*}{$\begin{array}{l}n \\
\mathrm{HCT}\end{array}$} & \multirow{2}{*}{$\begin{array}{l}n(\%) \\
\text { PCR }\end{array}$} & \multirow{2}{*}{$\begin{array}{l}\text { Odds ratio } \\
(95 \% \mathrm{Cl})\end{array}$} & \multirow[t]{2}{*}{ P-value } \\
\hline & & & & & \\
\hline Calves (<12 months) & 133 & 09 & $09(7)$ & 1.0 & reference \\
\hline Young females (12-48 months) & 136 & 23 & $48(35)$ & $5.1(2.1-9.8)$ & $<0.001$ \\
\hline Young males (12-48 months) & 136 & 27 & $49(36)$ & $5.2(2.4-10.2)$ & $<0.001$ \\
\hline Cows (> 48 months) & 168 & 48 & $71(42)$ & $6.1(3.8-9.1)$ & 0.001 \\
\hline Bulls and oxen (> 48 months) & 243 & 71 & $161(66)$ & $10.0(5.6-17.9)$ & $<0.001$ \\
\hline Total & 816 & $178(22)^{\mathrm{IR}-\mathrm{HCT}}$ & $338(41)^{\mid R-P C R}$ & & \\
\hline
\end{tabular}

$N$ number of animals examined, $n$ number of positive animals, (\%) percentage of animals infected, ${ }^{I R-H C T}$ the overall infection rate by $\mathrm{HCT}$, ${ }^{I R-P C R}$ the overall infection rate by PCR. Calves ( $<12$ months) were used as a reference category

to vectors between the cattle age groups [28]. In traditional grazing systems, suckling calves are restricted or grazed at homesteads and not allowed to graze with adults until weaned off [27]. This practice minimizes their chances of contact with the disease vectors when compared to adults. Additionally, calves are known to be protected by the effect of maternal immunity, which helps to keep parasitaemia low to almost undetectable levels [30]. This is further confirmed by the findings of this study, where up to $67 \%$ of infected calves had lowest parasitaemia scores (Table 2). The association between the prevalence of trypanosome infections and age of cattle might also be explained by differences in the attractiveness of animals of different ages to tsetse flies [7]. Studies on host preference have shown that tsetse flies are attracted most to odours of larger or older animals and least to calves [31].

The findings from this study have also indicated a significant association between sex and prevalence of trypanosome infections. Males had a significantly higher prevalence and risk of trypanosome infection than female cattle. The finding is consistent with Magona et al. [32] who showed that male cattle had a significantly higher prevalence of trypanosomes than females. In contrast, other studies [29, 32, 33] found no significant differences in the prevalence of trypanosome infections between males and females. Magona et al. [32] attributed this variation to the functional status of the animal such as being draught ox due to heavy stress from their use in ploughing. This stress

Table 2 Relative frequency (\%) of parasitaemia scores for trypanosome infections in cattle of different age categories and sex in Amuru and Nwoya districts, northern Uganda

\begin{tabular}{lllll}
\hline Age / Sex & $N$ & \multicolumn{3}{c}{ Parasitaemia score classes (\%) } \\
\cline { 3 - 5 } & & $1-2$ & $3-4$ & $5-6$ \\
\hline Calves (< 12 months) & 09 & 67 & 22 & 11 \\
Young females (12-48 months) & 23 & 43 & 35 & 22 \\
Young males (12-48 months) & 27 & 52 & 26 & 22 \\
Cows (> 48 months) & 48 & 54 & 25 & 21 \\
Bulls and oxen (> 48 months) & 71 & 27 & 17 & 56 \\
\hline
\end{tabular}

$N$ number of animals infected condition might contribute to increased susceptibility of male animals to trypanosome infections.

Trypanosoma vivax was found to predominate in the study area and contributed up to $77 \%$ of infections in cattle. This is in agreement with the findings of Magona et al. [34] who also indicated T. vivax as the most predominant trypanosome species in the Glossina fuscipes fuscipes infested areas. This could be explained by the vectorial capacity of G. fuscipes fuscipes [35] that accounts for over $90 \%$ of tsetse species infesting the study area (Angwech et $a l$. unpublished observation). Earlier studies have reported differences in vector competence and ability to transmit trypanosomes particularly between G. f. fuscipes and G. pallidipes. Glossina $f$. fuscipes reported to be a poorer transmitter of T. congolense than G. pallidipes was shown to have a higher transmission index for $T$. vivax compared to G. pallidipes [35]. In addition, T. vivax is known to have the shortest life cycle among all the trypanosome species recorded so far [36]. The predominance of $T$. vivax in the study area is consistent with the findings of several previous studies in Uganda [29, 37, 38]. The two districts are currently under the cattle restocking progamme of the government of Uganda and support of the nongovernmental organizations working in the region. The fact that all the three types of $T$. congolense were detected in cattle is not surprising. This could be due to the importation of infected animals from other geographical areas through the restocking programme [15].

ITS-PCR detected a higher prevalence of trypanosome infections (41\%) compared to parasitological tests; Haematocrit centrifuge technique (22\%). Haematocrit centrifuge technique is limited by having a low resolution and sensitivity that require a high threshold of detection of trypanosomes. PCR on the other hand, has a high sensitivity and specificity that considerably reduces the threshold levels of detection of infection to as low as one trypanosome per milliliter of blood [39, 40]. Besides, both districts are found in a trypanosomiasis endemic focus where most of the infections present in a chronic form characterized by low parasitaemia in which case PCR would be two to three times more sensitive. This 
further confirms the importance of PCR in epidemiological studies over parasitological methods.

\section{Conclusion}

In conclusion, the results of the present study indicate that the prevalence and intensity of trypanosomiasis infections are highly heterogeneous being associated with cattle age, sex and location.

\section{Limitations of the study}

The major limitations of this study were: firstly, it was not possible to document the enrolment of cattle or where they were brought from into the study area after the insurgency/conflicts. This was partly because some farmers who received the animals as donations from the support NGOs and the government did not know exactly where they came from.

Secondly, only the parasitologically positive animals were treated with a curative dose of diminazene aceturate due to the limited number of personnel involved in the field data collection and also due to the delay in PCR identification of the parasites.

Thirdly, even though PCR yielded bands which never corresponded to any known pathogenic trypanosome species band size were identified as trypanosomes, their profiles were different from the wild profile, and thus we recommend further investigation using more sensitive methods such as PCR- restriction fragment length polymorphism which are able to detect intra-species as well as interspecies variation to clarify this situation.

\section{Abbreviations \\ ITS-PCR: Internal Transcribed Spacer - Polymerase Chain Reaction; HAT: Human African Trypanosomiasis; HCT: Haematocrit Centrifugation Technique; BecA-ILRI: Biosciences Eastern and Central Africa - International Livestock Research Institute; SEGoLIP: Sequencing, Genotyping, Oligosynthesis and Proteomics; MSI: Millennium Science Initiative; TBE buffer: Tris-Borate-EDTA buffer; DNA: Deoxyribonucleic Acid.}

\section{Competing interests}

The authors declare that they have no competing interest.

\section{Authors' contributions}

AH, JHPN, EAO, JO and RAS conceived of the study, and participated in its design and coordination. $\mathrm{AH}$ and MNN participated in molecular analysis. $\mathrm{AH}, \mathrm{RO}$ and RE carried out the parasitological analyses. AH and GMM carried out statistical analyses, and AH drafted the manuscript. All authors read and approved the final manuscript.

\footnotetext{
Authors' information

'Department of Biology, Faculty of Science, Gulu University, P.O Box 166, Gulu, Uganda

${ }^{2}$ Biosciences Eastern and Central Africa (BecA), International Livestock Research Institute (ILRI) - Hub, Old Naivasha Road, P.O. Box 30709-00100, Nairobi, Kenya

${ }^{3}$ Department of Biology, University of Eastern Finland, P. O. Box 111, 80101 Joensuu, Finland

${ }^{\dagger}$ Deceased.
}

\section{Acknowledgements}

The authors would like to thank the staff of the veterinary departments of the two districts for their support during field data collection. Thanks also go to the farmers for providing the animals for the study. We are grateful to Ms. Margaret Akol and Mr. Odyek Godfrey for their technical assistance both in the field and in the laboratory. This project was supported financially by Gulu University MSI Trypanosome Diagnostic Project and the African Biosciences Challenge Fund (A.H). We are also indebted to Biosciences Eastern and Central Africa (BecA) - ILRI Hub, Nairobi for providing laboratory space and facilities for molecular analysis of the samples.

\section{Author details}

${ }^{1}$ Department of Biology, Faculty of Science, Gulu University, P.O. Box 166, Gulu, Uganda. ${ }^{2}$ Biosciences Eastern and Central Africa (BecA), International Livestock Research Institute (ILRI) - Hub, Old Naivasha Road, P.O. Box 3070900100, Nairobi, Kenya. ${ }^{3}$ Department of Biology, University of Eastern Finland, P. O. Box 11180101 Joensuu, Finland.

Received: 30 September 2014 Accepted: 30 September 2015

Published online: 08 October 2015

\section{References}

1. Ford LB. Civil conflict and sleeping sickness in Africa in general and Uganda in particular. Confl Health. 2007;1:6.

2. Aksoy S. Control of tsetse flies and trypanosomes using molecular genetics. Vet Parasitol. 2003;115:125-45.

3. Schofield CJ, Kabayo JP. Trypanosomiasis vector control in Africa and Latin America. Parasit Vectors. 2008;1:24.

4. Picozzi K, Fevre EM, Odiit M, Carrington M, Eisler MC, Maudlin I, et al. Sleeping sickness in Uganda: a thin line between two fatal diseases. BMJ. 2005;331:1238-41.

5. Kelly DW. Why are some people bitten more than others? Trends Parasitol. 2001;17:578-81.

6. Simukoko H, Marcotty T, Phiri I, Geysen D, Vercruysse J, Van den Bossche P. Heterogeneity in the trypanosomosis incidence of Zebu cattle of different ages and sex on the plateau of Eastern Zambia. Acta Trop. 2007;103:98-101.

7. Stoddard ST, Morrison AC, Vazquez-Prokopec GM, Soldan VP, Kochel TJ, Kitron $U$, et al. The role of human movement in the transmission of vector-borne pathogens. PLoS Negl Trop Dis. 2009;3:481

8. Woolhouse MEJ, Dye C, Etard JF, Smith T, Charlwood JD, Garnett GP, et al. Heterogeneities in the transmission of infectious agents: implications for the design of control programs. Proc Natl Acad Sci. 1997;94:338-42.

9. Kilpatrick AM, Daszak P, Jones MJ, Marra PP, Kramer LD. Host heterogeneity dominates West Nile virus transmission. Proc R Soc B. 2006;273:2327-33.

10. Lambrechts L, Knox TB, Wong J, Liebman KA, Albright RG, Stoddard ST. Shifting priorities in vector biology to improve control of vector-borne disease. Trop Med Int Health. 2009;14:1505-14.

11. Kabayo JP. Aiming to eliminate tsetse from Africa. Trends Parasitol. 2002;18:473-5.

12. Joshua RA, Obwolo MJ, Bwangamoi O, Mandebvu E. Resistance to diminazine aceturate by Trypanosoma congolense from cattle in the Zambezi Valley of Zimbabwe. Vet Parasitol. 1995;60:1-6.

13. Delespaux V, Geysen D, Van den Bossche P, Geerts S. Molecular tools for the rapid detection of drug resistance in animal trypanosomes. Trends Parasitol. 2008;24:236-42.

14. McNeil D. Drug companies and third world: a case study in Neglect. New York: New York Times; 2000.

15. Selby R, Bardosh K, Picozzi K, Waiswa C, Welburn SC. Cattle movements and Trypanosomes: restocking efforts and the spread of Trypanosoma brucei rhodesiense sleeping sickness in post-conflict Uganda. Parasit Vectors. 2013;6:281.

16. National Environment Management Authority (NEMA). State of the Environment Report for Uganda. Kampala: National Environment Management Authority (NEMA); 2012.

17. PAATIS. Programme Against African Trypanosomiasis: options for tsetse eradication in the moist Savannah Zone of West Africa. Technical and economic feasibility phase 1, GIS-based study. 2001:13. http://wwwnaweb.iaea.org/nafa/ipc/public/Tsetse-eradication-west-africa.pdf. Accessed 10 September, 2011

18. Kish L. Survey sampling. London: New York: John Wiley and Sons, Inc; 1968.

19. De-Lahunta A, Hable RE. Applied veterinary anatomy. USA: W.B. Saunders Company; 1986.

20. Woo PTK. The haematocrit centrifugation technique for the diagnosis of African trypanosomiasis. Acta Trop. 1970;27:384-6. 
21. OIE Terrestrial Manual, Chapter 2.4.18, Trypanosomosis (tsetse-transmitted). 2008 http://www.oie.int/fileadmin/Home/eng/Health_standards/tahm/ 2.04.18_TRYPANOSOMOSIS.pdf. Accessed 02 September, 2011.

22. ILCA (International Livestock Centre for Africa). The African Trypanotolerant Livestock Network. Indications from results 1983-1985. Addis Ababa: Ethiopia: ILCA; 1986. p. 138.

23. Desquesnes M, McLaughlin G, Zoungrana A, Dávila AM. Detection and identification of Trypanosoma of African livestock through a single PCR based on internal transcribed spacer 1 of rDNA. Int J Parasitol. 2001;31:610-4.

24. Desquesnes M, Ravel S, Cuny G. PCR identification of Trypanosoma lewisi, a common parasite of laboratory rats. Kinetoplastid Biol Dis. 2002;1:2.

25. Njiru ZK, Constantine CC, Guya S, Crowther J, Kiragu JM, Thompson RC, et al. The use of ITS1 rDNA PCR in detecting pathogenic African trypanosomes. Parasitol Res. 2005;95:186-92.

26. Rowlands GJ, Woudyalew M, Authie E, d'ieteren GDM, Leak SGA, Nagda SM, et al. Epidemiology of bovine trypanosomiasis in the Ghibe valley, southwest Ethiopia. 2. Factors associated with variations in trypanosome prevalence, incidence of new infections and prevalence of recurrent infections. Acta Trop. 1993;53:135-50.

27. Magona JW, Gereiner M, Mehlitz D. Impact of tsetse control on the age-specific prevalence of trypanosomosis in village cattle in Southeast Uganda. Trop Anim Health Prod. 2000;32:87-98.

28. Alemayehu B, Bogale B, Fentahun T, Chanie M. Bovine trypanosomiasis: a threat to cattle production in Chena district. Southwest Ethiopia. Open J Anim Sci. 2012;2:287-91.

29. Biryomumaisho S, Melville SE, Katunguka-Rwakishaya E, Cailleau A, Lubega GW. Livestock trypanosomes in Uganda: Parasite heterogeneity and anaemia status of naturally infected cattle, goats and pigs. Parasitol Res. 2013;112:1443-50.

30. Fiennes R. Pathogenesis and Pathology of Animal trypanosomiasis. In: Mulligan HW, editor. The African Trypanosomiases. London: Allen and Unwin; 1970. p. 729-50.

31. Torr SJ, Wangwiro TNC, Hall DR. The effect of host physiology on the attraction of tsetse (Diptera: Glossinidae) and stomoxys (Diptera: Muscidae) to cattle. Bull Ent Res. 2006;96:71-84.

32. Magona JW, Walubengo J, Odimin JT. Acute haemorrhagic syndrome of bovine trypanosomosis in Uganda. Acta Trop. 2008;107:186-91.

33. Fasanmi OG, Okoroafor UP, Nwufoh OC, Bokola-Oladele OM, Ajibola ES. Survey for Trypanosoma species in cattle from three farms in Iddo local Government Area, Oyo state. Sokoto J Vet Sci. 2014;12:57-61.

34. Magona JW, Walubengo J, Odiit M, Okedi LA, Abila P, Katabazi BK, et al. Implications of the re-invasion of Southeast Uganda by Glossina pallidipes on the epidemiology of bovine trypanosomosis. Vet Parasitol. 2005;128:1-9.

35. Moloo SK, Kutuza SB, Boreham PFL. Studies on Glossina pallidipes, G. fuscipes fuscipes and G. brevipalpis in terms of the epidemiology and epizootiology of trypanosomiasis in South-eastern Uganda. Ann Trop Med Parasitol. 1980;74:219-37.

36. Jordan AM. Recent Development in the ecology and methods of control of tsetse flies (Glossina species (Diptera: Glossinidae)): a review. Bull Entomol Res. 1974;67:523-74.

37. Waiswa C, Olaho-Mukani W, Katunguka-Rwakishaya E. Domestic animals as reservoirs for sleeping sickness in three endemic foci in south eastern Uganda. Ann Trop Med Parasitol. 2003;97:149-55

38. Waiswa C, Picozzi K, Katunguka-Rwakishaya E, Olaho-Mukani W, Musoke RA, Welburn SC. Glossina fuscipes fuscipes in the trypanosomiasis endemic areas of south eastern Uganda: Apparent density, trypanosome infection rates and host feeding preferences. Acta Trop. 2006;99:23-9.

39. Penchenier L, Dumas V, Grébaut P, Reifemberg JM, Cuny G. Improvement of blood and fly gut processing for diagnosis of trypanosomosis. Parasite. 1996:4:387-9.

40. Thumbi SM, McOdimba FA, Mosi RO, Jung'a JO. Comparative evaluation of three PCR based diagnostic assays for the detection of pathogenic trypanosomes in cattle blood. Parasit Vectors. 2008;1:46-50.

\section{Submit your next manuscript to BioMed Central and take full advantage of:}

- Convenient online submission

- Thorough peer review

- No space constraints or color figure charges

- Immediate publication on acceptance

- Inclusion in PubMed, CAS, Scopus and Google Scholar

- Research which is freely available for redistribution

Submit your manuscript at www.biomedcentral.com/submit 